\title{
Issues and options in high country farming \\ 4. Cycling nutrients for sustainable management
}

\section{K.F. O'CONNOR' and A.H. NORDMEYER ${ }^{2}$ \\ 'Centre for Mountain Studies, Lincoln University \\ ${ }^{2}$ New Zealand Forest Research Institute, Rangiora}

\section{Abstract}

Nutrient balances are recognised as the key to understanding the environmental context for sustainable management in pastorally used mountain lands and for monitoring possible effects of pastoral practices on the life-supporting capacity of soil. The paper draws on a larger survey of recent and current soil fertility research in the high country to examine briefly, three themes in nutrient cycling. The role of nutrient accessions to open systems is recognised for improved range. Current long-term revegetation studies show the need to take account of income from rock weathering. The importance of understanding the role of different plant species, soil amendments and pastoral practices in activating or impeding nutrient cycling proper is indicated from recent studies involving monitoring of exchangeable aluminium, comparing lupins with other legumes and studying the effects of planted conifers on the mineralisation of grassland organic matter. The dimensions and magnitudes of grazing-induced nutrient-transfers-are-outlined-in-relation-to-their. risks of loss from periodic hydrologic events, as well as recognising the roles of pasture improvement and grazing management in accelerating nutrient cycling.

Keywords: aluminium, grazing transfers, mineralisation of organic matter, nutrient balances, nutrient cycling, rock weathering, sustainable management

\section{-N utrient-balances-in-resource-accounting-}

The statutory significance of "safeguarding lifesupporting capacity of soil and ecosystems"

In preparation of this paper a larger survey of high country soil fertility research was prepared and available for participants in the NZ Grassland Association Conference at Oamaru (O'Connor et al. 1996). This paper is intended to be complementary to that larger survey, concentrating on three themes of nutrient cycling, in relation to their use for nutrient balances for the promotion of sustainable management.
Section 5 of the Resource Management Act defines "sustainable management", with its promotion the sole purpose of the Act. The phrasing in the Act leaves no option, no greater priority, than "safeguarding the lifesupporting capacity of air, water, soil, and ecosystems". Other elements in the definition of sustainable management have similar priority, though none greater.

There are also matters of national importance which are "to be recognised and provided for", which are outside the essential scope of sustainable management. These include the protection of outstanding natural features, the protection of areas of significant indigenous vegetation, the maintenance and enhancement of public access to lakes and rivers. There are other matters to which we should "have particular regard", including efficient use of resources, intrinsic values of ecosystems, recognition and protection of heritage values, maintenance and enhancement of amenity values, and habitat protection for trout and salmon.

All these examples of objectives pursued in the high country by various interest groups are listed by us, not to disparage them, but to emphasise the greater significance we should recognise in the Resource Management Act of "safeguarding life-supporting capacity of soil and ecosystems" as an integral part of sustainable management.

Nutrient cycling as a feature of soil conservation and comparative systems ecology

We see nutrient cycling as a characteristic dynamic feature of this new expression for "soil conservation". We wish to give it even more attention than was given in earlier times to the conservation of the physical fabric of the soil, and the protection of the soil body against soil-erosion-Accordingly, we-recognise-vegetationnot simply as a protective mantle against erosive agents such as rain, wind and frost, but as an integral part of the ecosystem of which the soil body and soil life are also part. Plants, microbes and the animals which feed both below and above ground, are in Norman Taylor's description the "organic regime", countering the "wasting regime" by which the products of weathering were removed from the soil.

Grazing animals are an integral part of the ecosystems we now have to deal with as pastoral or farm land. Ruminants had no previous part in the 
indigenous grassland ecosystems into which they were brought by Europeans. That fact simply serves to emphasise that we are dealing with different ecosystems that have grazing mammals in them or still carry their imprint, ecosystems true, but distinct from the natural ecosystems to be restored or protected and preserved as natural areas without animal influence. We consider the comparative study of nutrient cycling in natural ecosystems, pastoral ecosystems and afforested ecosystems, to be one of the most important areas for research emphasis in the immediate future.

We wish to emphasise that these are open systems, not closed systems, with which we are concerned for nutrient cycling. As well as cycling proper, there are inflows and outflows. Familiar inflows to nutrient cycles of pastoral systems are fertiliser applications and nitrogen fixation. In the first theme of our paper, gives attention to the need for taking some quantitative account of nutrient influxes from mineral weathering.

The second theme concentrates on some of the processes which affect thcactual cyclic flow of nutrients within different kinds of ecosystems. We focus particular attention (i) on the interaction of elements in soil-plant systems, especially phosphorus, aluminium and bases; (ii) on the influence of different species of plants on activating or deactivating nutrients in pools of different kinds: and (iii) on the particular role of some animal and soil management practices in activating still or sluggish pools.

The third theme acknowledges that nutrient losses from landscape systems may not occur smoothly or regularly over time, but may be much more dependent on periodic major events such as vegetation burning, rainstorms and floods. Outflows from nutrient cycles will take place as export of produce from the system, and also through nutrient escapes by way of mobile members of ecosystems. In this respect we give particular attention to the role of grazing animal behaviour and its interaction with management. with landscape features and with meteorologic events.

\section{Influx of nutrients in mountain revegetation systems}

\section{Growth of soil}

One of the dimensions of soil fertility research in sustainable management to which we have directed attention (O'Connoret al.1996), was the upward growth of soil in the course of revegetation or vegetation development. We have given there some practical examples of the phenomenon of soil growth and its implications to our attempts to measure differences over time in chemical composition of soil, sampled to the same depth from the soil surface. When the soil has grown, sampling to constant depth from the soil surface fails to sample the soil body over the same horizon as was previously studied. Failure to correct for such a sampling distortion may lead us to infer a loss of nutrients where in fact no loss has occurred. It should be noted that this phenomenon of soil growth can affect not only the nutrient balances of primary revegetation experiments but can also alter balances calculated for topsoil and even subsoil change under pasture development regimes. Correcting calculations by determining volume weights may not be sufficient to overcome this problem. If careful nutrient balances are to be interpreted from successive samplings, some provision has to be made to survey the surface of the soil to allow for the increased soil volume to be taken into account and to allow sampling of soils to the same depth from the original datum.

\section{Nitrogen accumulation over time during revegetation succession}

Figure 1 illustrates the increasing amounts of nitrogen accumulation in different compartments of the ecosystem as a succession of legumes occurred on eroded subsoil at Hut Creek in the Craigieburn Forest. These were sown clovers for the first three or four years, a succession of volunteer lotus for another nine or ten years, and then perennial lupin for the next 16 years up to the present, progressively adapted to the initial decline in applied phosphorus fertility and to residual exchangeable aluminium.

Nitrogen accumulation was at first most evident in turf and the new topsoil, with little storage in herbage and roots. During the lotus dominant phase, the

Figure I Accumulation of nitrogen after 5, 14, 21, and 30 years in different ecosystem compartments in a revegetation succession of sown and volunteer legumes on eroded subsoil at Hut Creek in the Craigieburn Forest. (Note that the time scale is not strictly drawn.)

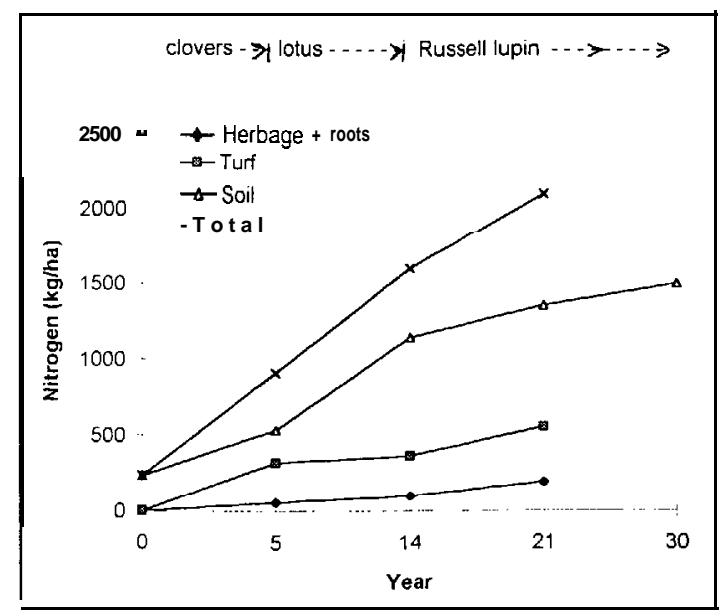


uppermost $100 \mathrm{~mm}$ of soil continued to accumulate $\mathbf{N}$, but as lupins became dominant, $\mathrm{N}$ accumulation in turf, herbage and rootstocks was again evident and $\mathrm{N}$ accumulation in soil continued down to $150 \mathrm{~mm}$ (not shown). Over the last 16 years of lupin dominance, there has been a dramatic rise in numbers and biomass of earthworms from close to zero to more than 100 per square metre, and an accompanying rise in exchangeable calcium to $16 \mathrm{me}$. per $100 \mathrm{~g}$ of soil. Over the last nine years, only a small proportion of the plots have been available for destructive sampling, so that biomass $\mathrm{N}$ accumulation has not yet been recorded.

Rock weathering as a source of nutrients

As we recorded in the larger research survey (0'Connor et al. 1996, table 2), mean annual rates of accumulation in biomass up to 21 years in three revegetation experiments on subsoil have been $104 \mathrm{~kg} / \mathrm{ha} \mathrm{N}, 4.7 \mathrm{~kg} /$ ha $P, 50 \mathrm{~kg} / \mathrm{ha} \mathrm{K}, 7.5 \mathrm{~kg} / \mathrm{ha} \mathrm{Mg}$ and $22 \mathrm{~kg} / \mathrm{ha} \mathrm{Ca}$. We have there also recorded the approximate amounts ot these elements in stones of $\mathbf{2 - 5} \mathrm{mm}$ in the upper 200 $\mathrm{mm}$ of subsoil, otherwise nutrient-impoverished. This small-stone pool is seen as an indicator of the nutrient store, from which nutrients have apparently been weathering at about $1 \%$ per year to enter the ecosystem pool for the measured biomass accumulation rates to be achieved.

There appears to have been little assessment of current rates of weathering of rock material in New Zealand soils. The study of rock weathering rinds has been concentrated on exposed rock screes, as a device for scree aging. Rock fragment weathering within the soil body where materials are exposed to biological influences is probably much more rapid than what is indicated from exposed screes. Zaboski (1990) presented in New Zealand a review of the role of mineral weathering in long term site productivity, but she drew on a range of different kinds of studies in Europe and North America to show that annual inputs from weathering in forested ecosystems varied widely with kind of parent material, climate and vegetation type, and with stage of soil development. Annual ecosystem input rates for $\mathrm{Mg}$ and $\mathrm{Ca}$ cited above are well within the ranges she reported for those elements, that for $K$ is above the maximum rate she reported. This might be expected in the very early stages of soil renewal from fresh rock fragments on our mountain slopes. Clearly, inputs from weathering should be an important part of nutrient balance sheets in New Zealand high country. They need to take account of the kind of rock and its weathering history, just as it is necessary to take account of the fact that the parent material for a new soil is often in part the transported or residual product of earlier soil formation.
Activation and impedance of nutrient cycling

The phosphorus, aluminium and cation impasse The larger survey of soil fertility research in the high country already referred to (O'Connor $e t$ al. 1996), has shown how earlier soil microbiological research on Craigieburn terraces by the late John Robinson (Robinson \& MacDonald 1964), and supported in some soils of the Otago sequence studied by the Soil Bureau team (Molloy \& Blakemore 1974), pointed to sluggish soil metabolism under the short tussock grassland turf. Williams et al. (1977) characterised such systems as "pseudo-aged", prematurely brought to something like a terminal steady state by their progressive degradation from forest to tall tussock grassland, and eventually to a sparse fescue tussock and browntop-dominant turf. Such sluggish soil-system metabolism is not conducive to nutrient cycling (O'Connor 1967). There are three features we wish to outline here (i) the interactive, biologically inactivating role of soil aluminium and the function of fertilisers and particular plant species in altering the effect of this impediment to nutrient cycling; (ii) the function of afforestation in overcoming such impediments; (iii) the function of intensive grazing management in activating or accelerating nutrient cycling.

From Alan Sinclair's earlier work in the study of the P-supplying power and P-buffering power (or Pretention) of a wide range of topsoils from the Mackenzie Basin (O'Connor et al. 1996), we indicated the effect of exchangeable Al on $P$ uptake and with it the uptake of other.nutrients. Al may inhibit root growth and thereby impede nutrient cycling and may also interfere with mineralisation of soil organic matter. We outlined the pedogenetic relationship of $A \mathrm{I}$ in subsoils from Tonkin and Basher's study across Canterbury and the West Coast, and showed the relationship of extractable Al and P-retention at successive depths in soils of contrasting age and precipitation.

Figure 2 presents data from the Mackenzie Basin and the Hakatere Basin for successive depth sampling of two members of the Pukaki soil set. The uppermost example, from Balmoral in the Mackenzie Basin shows that a critical level of extractable Al (2 me.\%) and a critically low ratio of combined cations to aluminium (<1) both occur at from 200 to $400 \mathrm{~mm}$ depth. In shallower topsoils and again at greater depths, these Al effects and levels of Bray-2 $P$ are both improved. In the Pukaki soil from Mt Possession in the Hakatere Basin, Davis (1991) had reported effects of different $P$ levels on different legumes and Svavarsdottir (1995) has indicated the longer term effects of different $P$ levellegume combinations on associated plant communities. Figure 2 here shows how, without $P$ fertiliser, the 
Figure 2 Profiles of some soil chemical properties in members of Pukaki soil set at Balmoral in the Mackenzie Basin (uppermost), and at Mt Possession in the Hakatere Basin (middle, without fertiliser, and lowest, with $400 \mathrm{~kg} / \mathrm{ha} P$ applied as fertiliser 15 years earlier and sown to legumes). Available phosphorus is Bray-2 P ppm, Aluminium is me.\% extracted in KCl. Ratio of exchangeable cations: aluminium as shown.

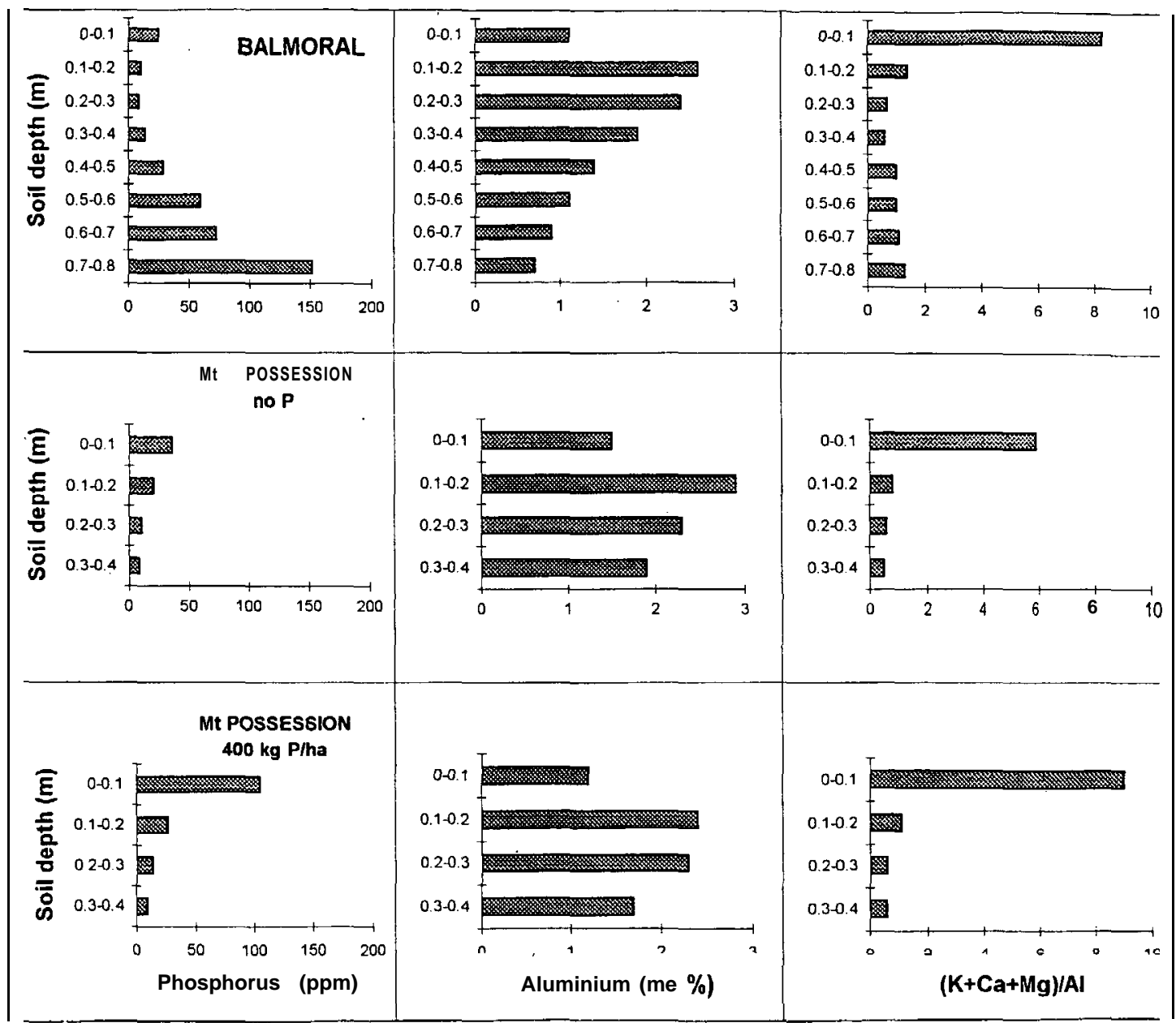

extractable $\mathrm{Al}$ and ratio of cations: Al now remain critically adverse below $100 \mathrm{~mm}$ depth. Where a high level of $P(400 \mathrm{~kg} \mathrm{P} / \mathrm{ha}$ ) was applied 15 years before, soils under a wide range of legumes had not only been improved in Bray-2 $\mathrm{P}$, especially in the uppermost sampling layer, but they had been ameliorated to some degree down to $200 \mathrm{~mm}$ with respect to Al.

Lupins, hawkweed and conifer effects

It has also been shown (O'Connor et al. 1996, figure 3 ) that at low levels of applied $P$, lupins were superior to clovers at Mt Possession in enhancing the topsoil level of exchangeable $\mathrm{Ca}$ and reducing the level of exchangeable Al. This apparent specific beneficial effect of lupins which we earlier recognised in exchangeable Ca enhancement and accompanying earthworm buildup in revegetation of Al-rich subsoils, warrants more attention, It offers the prospect of further activation of nutrient cycling, without incurring the high levels of $\mathbf{P}$ application indicated in these soils for clover culture. The mechanisms by which such effects are brought about need to be investigated. If as we have suggested (O'Connor et al. 1996, p.12), chelation of Al is involved, this would be a more satisfactory way of coping with Al than by selectively avoiding Al uptake (worsening the environment, perhaps, for companion species), or by counteracting Al effects with high levels of lime, or perhaps by sequestering Al into some 
ecosystem compartment from which it has to be set free eventually.

Some attention has been given to the effects of soil fertility and fertiliser on hawkweed growth and incidence. We need more explicit research evidence of the effects of Hieracium species on soil fertility and thereby on plant communities which they invade. In our larger review, (O'Connor et al. 1996, figure 4) we have illustrated from the current work of Boswell and Espie at Tara Hills the increase in soluble Al under hawkweed patches, associated with increased soil acidification. How acidification is fostered, whether by plant exudation or by accumulation into hawkweed root and rhizome tissue of bases such as $\mathrm{Mg}$ and $\mathrm{Ca}$, we have insufficient critical data to tell. How hawkweeds tolerate or evade the soluble $\mathrm{Al}$ that they generate, we likewise lack critical evidence to discern.

The outstanding species effects on high country grassland soil fertility that have been clarified in recent years are thosc of planted conifers. From eariier work of Davis \& Lang (1991), and especially the more recent soil $P$ fractionation of Condron et al. (1996), it is now clear that increase in available $\mathrm{P}, \mathrm{N}$, and $\mathrm{S}$ under conifer plantations is from mineralisation of the large organic matter pool residual from grassland. Davis (1995), with pot trials with Pinus radiata seedlings and cocksfoot in unamended grassland soils, has shown this effect, from the effect of a year's growth of pine compared with cocksfoot, on chemical properties of soils. These findings and the evidence that they apply throughout the montane zone of the North Otago-Canterbury high country -(Beltonet-al-1995) have enormous implications for the activation of nutrient cycling in future land use systems and for the efficiency of pastorally invested nutrients.

\section{Pastoral management effects}

Acceleration of nutrient cycling was first proposed for the high country by O'Connor \& Clifford (1966) as a contribution to fertiliser efficiency, with an emphasis on nitrogen cycling (O'Connor 1967). As pointed out in our larger survey, there is substantial evidence from the high levels of herbage production obtained from these early intensive grazing management experiments, that accelerated nutrient cycling in fact occurred, with some increase in ryegrass and cocksfoot, without necessarily bringing about a rapid transition away from clover dominance. In later experiments, such as Bruce Allan's at Tara Hills (Allan 1985) the most intensive forms of management have not maximised herbage or animal production, but they have been associated with better distribution of animals and faecal returns, and with higher topsoil Olsen-P (Thorrold et al. 1985). At farm scales, we have widespread evidence of higher stock loads per hectare on improved high country grasslands as a function of increased subdivision fencing (O'Connor et al. 1982), and there is widespread belief among farmers that mob-stocking is effective in obtaining more even distribution of animal returns. The distribution patterns of grazing, of nutrient returns from animals, and of nutrient cycling need testing and confirmation at farm paddock scale.

\section{Losses in pastoral systems}

Nutrient transfer through animals and its interaction with landscape and hydrology

Farm outputs from high country pastoral systems over the last 140 years have been principally wool, and secondarily livestock. There is a temptation to consider the export of nutrients involved in these farm outputs and the estimated loss of nutrients involved in soil erosion and tussock grassland burning as the principal items in the debit side of a nutrient balance. This is an inadequate approach for nutrient balance purposes. Sulphur and nitrogen exports from the pastoral system as produce have probably been the largest system outputs. For example, export of $S$ may have exceeded 60000 tonnes as wool from the pastoral high country since its first settlement. Net $S$ losses through consumption by animals, allowing for returns to the grazing area, may have been much greater and would have greatly exceeded the $S$ lost through periodic burning. Work is current to revise the model and submodels developed by Peter Harris for different sectors of the high country and used by O'Connor \& Harris $(199 \overline{2})$, so that these issues can be examined and explained more thoroughly. Essential considerations only are outlined here.

Nutrients in herbage consumed by grazing animals but not returned to the grazing area can be considered to have been lost, at least temporarily, from the grazing system. Whether such losses as urine or faeces transferred to camping areas become permanent depends on the climate, the hydrology of the landscape system, and interactions of periodic events such as rainstorms or snowmelts generating_surface-flow or deep percolation. Reviews of losses of nutrients from New Zealand pastoral systems (O'Connor 1990; Ward et al. 1989) indicate,that the magnitude of losses is affected by the scale of the system, but they also suggest that aggregations of livestock returns are especially vulnerable to loss. From evidence gathered in the larger survey (O'Connor et al. 1996) we propose summary ideas of four gradients in animal-mediated nutrient transport. From table 4 in that survey, we propose an increasing upslope gradient in faecal returns, at least in larger paddocks or hilly blocks. From table 5, derived from Peter Mclntosh's work on Longslip before 
development, we discern a $50 \%$ to $150 \%$ increase in topsoil nutrient levels' towards sheep camps, in comparison with similar sites lower or higher on the ridge which were not sheep camps. Again from Peter McIntosh's work, we propose an increased gradient of nutrients from shady to sunny aspects, especially of bases, attributable in part at least to animal transfer. Finally from table 6 from Phil Tonkin's detailed study at Hunua, we demonstrate the magnification of $\mathrm{Ca}$ and $S$ in a seepage zone above the general levels measured there, indicating a nutrient gradient towards such seepage zones, perhaps mediated by accumulations in stock camps, as has also been shown for some cases of overland storm flow (Ward et al. 1989).

\section{Perspectives for nutrient balances}

Nutrient balances as a guide or criterion for promoting sustainable management will be useful only if they are devised for the kind of terrain and pastoral system to which they are to be applied. For example, the net nutrient balances over the 30 years from 1950 reported for the dry eastern sector of the Upper Waitaki (O'Connor \& Harris 1992) indicate net annual losses ranging from $3-9 \mathrm{~kg} / \mathrm{ha} \mathrm{N}, 0.1-0.3 \mathrm{~kg} / \mathrm{ha} P$. $0-0.2 \mathrm{~kg} / \mathrm{ha}$ $\mathrm{S}$. The mean annual rate within each of these ranges is derived from a 30-year period in which fertiliser use rose from zero to a level where the amounts of superphosphate applied per livestock unit probably exceeded the national average for all classes of sheep farms. Topdressing would by then have been applied to some $20 \%$ of the total area, which in turn may have carried more than 80 or $90 \%$ of the total livestock load.

Such overall average rates mean little either in time or in space. Clearly, the improved country would be in positive annual balance for N P S and possibly $\mathrm{Ca}$. This would probably be despite increased drainage losses of some nutrients. Nutrient balances for unimproved land would have to be determined by taking account of current stock load. It is conceivable that for most nutrients except $\mathrm{S}$, losses from some unimproved terrains may be matched by gains from rock weathering. If nutrient balances are to be used as criteria or guides, we shall have to develop or adapt models to be relevant to the systems that we simulate, we shall have to validate such models by use of reference areas as McIntosh et al. (1996) have established, and we shall have to extend those reference areas to include both natural condition benchmarks and stable management benchmarks relevant to each kind of terrain. That last role is the continuing value of established facilities like Mt John. We are appalled at the prospect of its being closed down.

If we want to practise burning for scrub or talltussock control, we shall have to use nutrient models appropriate to that practice and validate them against monitored, real world situations. It is time for an end to high country disputes where each side argues from an inadequate information base. It is also time to give up the idea of starting up more "plot research" as our sole or principal means of adequately informing decisionmakers. High country farmers now look to new means to gather and integrate information for grassland management. It is time for the rest of the grassland community to respond to this keen interest and to sustain it with well designed participative science strategies.

\section{REFERENCES}

Allan, B.E. 1985. Grazing effects on pasture and animal production from oversown tussock grassland. Proceedings of the New Zealand Grassland Association 46: 119-t 25.

Belton, M.C.; O'Connor, K.F.; Robson, A.B. 1995. Phosphorus levels in top-soils under conifer plantations in Canterbury high country grasslands. New Zealand forestry science 25(3): (in press).

Condron, L.M.; Davis, M.R.; Newman, R.H.; Cornforth, I.S. 1996. Influence of conifers on the forms of phosphorus inselected New Zealand grassland soils. Biology and fertility of soils 21: 37-42.

Davis, M.R. 1991. The comparative phosphorus requirements of some temperate perennial legumes. Plant and soil 133: 17-30.

Davis, M.R. 1995. Influence of radiata pine seedlings on chemical properties of some New Zealand montane grassland soils. Plant and soil 176: 255262.

Davis, M.R. Lang, M.H. 1991. Increased nutrient availability in topsoils under conifers in the South Island high country. New Zealand journal of forestry science 21: 165-I 79.

McIntosh, P.D.; Ogle, G.I.; Patterson, R.G.; Aubrey, B.; Morriss, J.; Giddens, K. 1996. Changes in surface soil nutrients and sustainability of pastoralism on grazed hilly and steep land, South Island New Zealand. Journal of range management 49: 361367.

Molloy, L.F.; Blakemore, L.C. 1974. Studies on a climosequence of soils in tussock grasslands. 1. Introduction, sites and soils. New Zealand journal of science 17: 233-255.

O'Connor, K.F. 1967. The improvement and utilisation of tussock grasslands: a scientist's viewpoint. Proceedings of the New Zealand Grassland Association 28: 59-78.

O'Connor, K.F. 1990. Pasture and soil fertility. pp. 157-196. In: Langer, R.H.M. (ed.), Pastures: their ecology and management. Auckland: Oxford University Press. 
O’Connor, K.F.; Clifford, P.T.P. 1966. Fertiliser economy in run development Review Tussock Grasslands and Mountain Lands Institute 11: 4649.

O'Connor, K.F.; Costello, E.J.; Abrahamson, M. 1982. Fencing and fertiliser in pastoral development: an analysis of farm scale performance in the Waitaki high country. Review Tussock Grasslands and Mountain Lands Institute 41: 49-59.

O’Connor, K.F.; Harris, P.S. 1992. Biophysical and cultural factors affecting the sustainability of high country pastoral land uses. pp. 304-313. In: Henriques, P.R. (ed.), The Proceedings of the International Conference on Sustainable Land Management, Napier, Hawke's Bay, New Zealand, 17-23 November 1991. Napier: Hawke's Bay Regional Council.

O'Connor, K.; Nordmeycr, A.: Condron, L.; Davis, M.; Espie, P.; Gibson, R.; Harris, P.; Metherell. A.; Patterson, R.; Sinclair, A.; Svavarsdottir, K.; Tonkin, P. 1996. Safeguarding the life-supporting capacity of soil and ecosystems: a survey of the role of high country soil fertility research. Lincoln: Centre for Mountain Studies.

Robinson, J.B.; Macdonald, G.M. 1964. Respiration and bacterial growth in a New Zealand grassland soil. New Zealandjournal of agricultural research 7; 569-582.
Svavarsdottir, K. 1995. Effects of added nutrients on species composition in native tussock grasslands of New Zealand. Unpublished PhD thesis, Department of Plant Science, Lincoln University, Canterbury.

Thorrold, B.S.: O’Connor, K.F.: White, J.G.H. 1985. Management influences on sheep behaviour, dung distribution and soil phosphate. Proceedings of the New Zealand Grassland Association 46: 127-134.

Ward, J.C.; O'Connor, K.F.; Gan, Wei-bin. 1989. Phosphorus losses through transfer, run-off and soil erosion.In: Teissen, H. (ed.), Proceedings of SCOPE International Symposium on Phosphorus Requirements for Sustainable Agriculture in Asia and Oceania, Los Banos, Philippine Islands.

Williams, P.A.; Nes, P.; O’Connor, K.F. 1977. Macroelement pools and fluxes in tall-tussock (Chionochloa) grasslands, Canterbury, New Zealand. New Zealand journal of botany 15: 443-476.

Zaboski, D. 1990. Role of mineral weathering in longterm site productivity. pp. 55-71. In: Dyck, W.J.; Mees, C.A. (eds), Impact of Intensive Harvesting on Forest Site Productivity. Proceedings IEA/BE A3 Workshop, South Island, New Zealand, March 1989. Forest Research Institute Bulletin No 159, FRI Rotorua. 